\section{Drugged driving}

In a $C M A J$ news article $^{1}$ Wanniarachige states that it is difficult to establish a dose-effect response between cannabis use and driving risk. A review of the literature by Ramaekers and colleagues ${ }^{2}$ concludes that the "degree of performance impairment observed in experimental studies after doses up to $300 \mu \mathrm{g} / \mathrm{kg}$ THC [tetrahydrocannabinol] were equivalent to the impairing effect of an alcohol dose producing a blood alcohol concentration $\geq 0.05 \mathrm{~g} / \mathrm{dl}$, the legal limit for driving under the influence in most European countries." Ramaekers and colleagues note that "[s]ignificant performance impairment emerges at serum THC concentrations $>2 \mathrm{ng} / \mathrm{ml}$ and crash risk significantly increases at serum THC concentrations between $4-10 \mathrm{ng} / \mathrm{ml}$."' They observe that "combined use of THC and alcohol produces severe driving impairment and sharply increases the risk of drivers' accident culpability as compared to drug-free drivers even at low doses."2

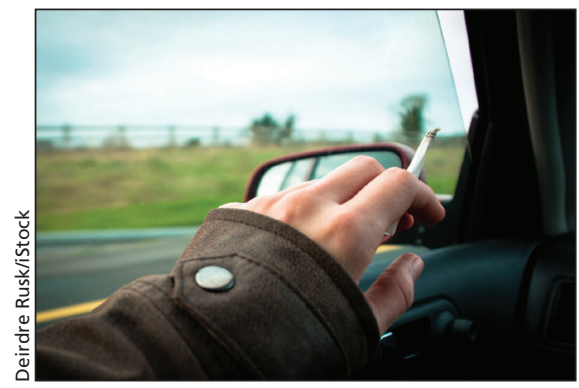

A link exists between attention-deficit/ hyperactivity disorder (ADHD) and driving risk. ${ }^{3}$ The Dunedin study presents data on the effects of chronic frequent cannabis use starting in the teen years, showing toxic effects on cognitive neurodevelopment, which produce irreversible clinical syndromes indistinguishable from ADHD, and apparently irreversible loss of IQ, even after discontinuation of cannabis. ${ }^{4}$ This merits careful study by those advising legislators about the risks of intoxicated driving.

Laurence Jerome MBChB MSc Western University, London, Ont.

\section{References}

1. Wanniarachige D. Drugged-driving: putting the brakes on pot use. CMAJ 2015;187:315.

2. Ramaekers JG, Berghaus G, van Laar MW, et al. Dose related risk of motor vehicle crashes after cannabis use: an update. Drug Alcohol Depend 2004;73:109-19.

3. Jerome L, Segal A, Habinski L, et al. What we know about ADHD and driving risk: a literature review. J Can Acad Child Adolesc Psychiatry 2006; $15: 105-25$

4. Meier MH, Caspi A, Ambler A, et al. Persistent cannabis users show neuropsychological decline from childhood to midlife. Proc Natl Acad Sci USA 2012;109:E2657-64

CMAJ 2015. DOI:10.1503/cmaj.1150041

\section{Bariatric surgery saves lives}

Fletcher and Patrick suggest that the use of bariatric surgery "is always going to be limited and a last resort."1 I disagree. Bariatric surgery has a major impact on type 2 diabetes. ${ }^{2}$ Over 6000 bariatric surgeries are performed annually in Canada, one-third in Quebec alone. ${ }^{3}$ If the United States is any indicator, we should be doing 20000-25000 surgeries per year.

Many Canadians go very south of the border (Mexico, Dominican Republic, Costa Rica, Brazil), where surgery is often performed in facilities whose conditions are unknown. Many patients come home with complications, resulting in a much higher cost to taxpayers. ${ }^{4}$

It is possible to increase the number of Canadian operations to $50000-$ 60000 per year, and have $1 \%$ of the population treated within seven years. The investment would be recouped within three to five years. ${ }^{5}$ At present, bariatric surgery is the only proven treatment for severe obesity as societal changes are unlikely to have an impact in the next decade. ${ }^{6}$

\section{Michel Gagner MD}

Hôpital du Sacré-Coeur, Montréal, Que.

\section{References}

1. Fletcher J, Patrick K. A political prescription is needed to treat obesity. CMAJ 2014;186:1275.

2. Schauer PR, Bhatt DL, Kirwan JP, et al. Bariatric surgery versus intensive medical therapy for diabetes: 3-year outcomes. $N$ Engl J Med 2014;370: 2002-13.

3. Bariatric surgery in Canada. Ottawa: Canadian Institute for Health Information; 2014. Available: https://secure.cihi.ca/free_products/Bariatric_Surgery _in_Canada_EN.pdf.
4. Sheppard CE, Lester EL, Chuck AW, et al. Medical tourism and bariatric surgery: Who pays? Surg Endosc 2014:28:3329-36.

5. Sampalis JS, Liberman M, Auger S, et al. The impact of weight reduction surgery on health-care costs in morbidly obese patients. Obes Surg 2004; 14:939-47.

6 Collier R. Calls for a better food guide. CMAJ 2014;186:1281.

CMAJ 2015. DOI:10.1503/cmaj.1150042

\section{Radon risks}

I thank $C M A J$ for highlighting the topic of radon-related cancer. ${ }^{1}$ Very few Canadians are aware of radon and the risks it poses. This is a substantial hurdle in the battle against radon-related malignancy. There is another hurdle: many physicians do not fully understand the risks related to radon.

The topic of radon was mentioned briefly during my medical school training. I did not pay much attention to it, given the vast number of other topics I had to learn. I suspect most of my colleagues did the same. Of the thousands of patient encounters in which I have been involved, I've never heard a physician ask about radon, nor have I.

Excellent resources are readily available. Health Canada's website (www .hc-sc.gc.ca/ewh-semt/radiation/radon/ index-eng.php) is an excellent introduction and should be required reading for all medical students and residents.

\section{Michael Paci MD CM}

Department of Neurology and Neurosurgery, McGill University Health Centre, Montréal, Que.

\section{Reference}

1. Eggertson L. More needed to reduce radon-related cancer. CMAJ 2015;187:485.

CMAJ 2015. DOI:10.1503/cmaj.1150043

\section{Letters to the editor}

In submitting a letter, you automatically consent to having it appear online/in print. All letters accepted for print will be edited for space and style. See www.cmaj.ca for full versions and competing interests. 